\title{
Synthesis and Molecular Structure of $\mathrm{Ph}_{3} \mathrm{GeBO}_{2} \mathrm{C}_{2} \mathrm{Me}_{4}$
}

\author{
Eric G. Bowes,* Christopher M. Vogels,* Andreas DeCKen, ** and Stephen A. WestcotT*† \\ *Department of Chemistry and Biochemistry, Mount Allison University, Sackville, NB E4L 1G8 Canada \\ **Department of Chemistry, University of New Brunswick, Fredericton, NB E3B 5A3 Canada
}

\begin{abstract}
The germanium-boron compound, $\mathrm{Ph}_{3} \mathrm{GeBpin}$ (pin $=1,2-\mathrm{O}_{2} \mathrm{C}_{2} \mathrm{Me}_{4}$ ), was isolated and the molecular structure was determined by a single crystal X-ray diffraction study at $188 \mathrm{~K}$. The compound crystallizes in an orthorhombic system, space group $P c a 2_{1}$ and $Z=8$ with cell parameters of $a=16.669(4) \AA, b=9.933(2) \AA, c=26.907(6) \AA, V=4455.0(17) \AA^{3}$. The $R_{1}[I>2 \sigma(I)]$ and $w R_{2}$ (all data) values are 0.0463 and 0.1196 , respectively, for all 9468 independent reflections. The molecular structure analysis reveals the boron atom lies in a roughly trigonal environment that contains one pinacolato group. The asymmetric unit contains two independent molecules and the B-Ge bond distances for the two molecules are 2.073(10) and 2.051(14) ̊.
\end{abstract}

(Received February 18, 2016; Accepted April 21, 2016; Published on web August 10, 2016)

The addition of boron-element (B-E, where $\mathrm{E}=\mathrm{H}, \mathrm{B}, \mathrm{Si}, \mathrm{Ge}$, etc.) bonds to unsaturated molecules constitutes a number of remarkably important reactions in organic synthesis for the production of new compounds for the pharmaceutical and agricultural industry. ${ }^{1}$ Reactions with heavier main group elements $(\mathrm{E}=\mathrm{Si}, \mathrm{Ge}$, etc. $)$ usually result in organodimetalloid compounds which are highly versatile building blocks that are otherwise difficult to synthesize. ${ }^{2}$ Our recent efforts in this area have focussed on $\mathrm{B}-\mathrm{E}\left(\mathrm{E}=\mathrm{S},{ }^{3} \mathrm{P}^{4}\right)$ addition reactions to a variety of organic substrates. Boronate ester groups $\left[\mathrm{B}(\mathrm{OR})_{2}\right]$ have been utilized to ensure a B-E single bond by minimizing any potential $\pi$-dative bonding from the main group base (E) with the empty orbital on the boron atom. As part of this investigation we have begun to expand upon the chemistry of compounds containing B-Ge bonds.

In this study, we have found that $\mathrm{Ph}_{3} \mathrm{GeBpin}$ (pin = 1,2- $\left.\mathrm{O}_{2} \mathrm{C}_{2} \mathrm{Me}_{4}\right)(\mathbf{1})$, as shown in Fig. 1, could be readily prepared in good yield $(61 \%)$ by the reaction of $\mathrm{Ph}_{3} \mathrm{GeLi}(8 \mathrm{mmol})$ with $i$-PrOBpin $(16 \mathrm{mmol})$ in $\mathrm{Et}_{2} \mathrm{O}(40 \mathrm{~mL})$. The reaction was initially performed in a bath of dry ice and isopropanol and was allowed to warm to room temperature as the reaction proceeded. A white precipitate formed and was collected by suction filtration then discarded. The volume of the pale yellow filtrate was reduced by half under vacuum and the solution stored at $-30^{\circ} \mathrm{C}$. Colorless parallelepiped crystals of $\mathbf{1}$ formed and were collected by suction filtration. The ${ }^{1} \mathrm{H}$ and ${ }^{13} \mathrm{C}\left\{{ }^{1} \mathrm{H}\right\}$ NMR data are consistent with the molecular structure of $\mathbf{1}$ and the ${ }^{11} \mathrm{~B}$ NMR spectrum shows a broad resonance at $35 \mathrm{ppm}$ which is

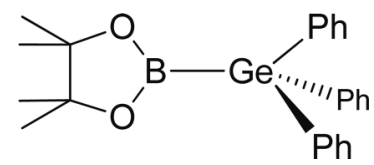

Fig. 1 Chemical structure of compound $\mathbf{1}$.

† To whom correspondence should be addressed.

E-mail: swestcott@mta.ca indicative of the boron atom existing in a three coordinate environment.

Single-crystal X-ray diffraction measurements were performed and a hemisphere of data was collected on a Bruker AXS P4/SMART 1000 diffractometer using $\omega$ and $\phi$ scans with a scan width of $0.3^{\circ}$ and $10 \mathrm{~s}$ exposure times. The detector distance was $5 \mathrm{~cm}$. The crystal was a non merohedral twin and the orientation matrix for the major component was determined (CELL_NOW). ${ }^{5}$ The data were reduced (SAINT) ${ }^{6}$ and corrected for absorption (SADABS). ${ }^{7}$ The structure was solved by direct methods and refined by full-matrix least squares on

Table 1 Crystal and experimental data

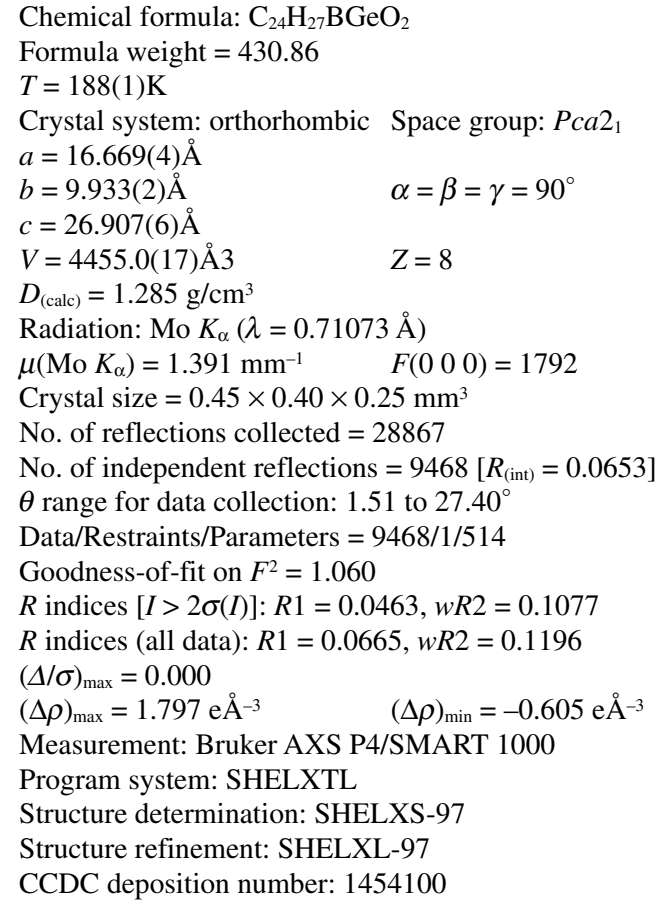




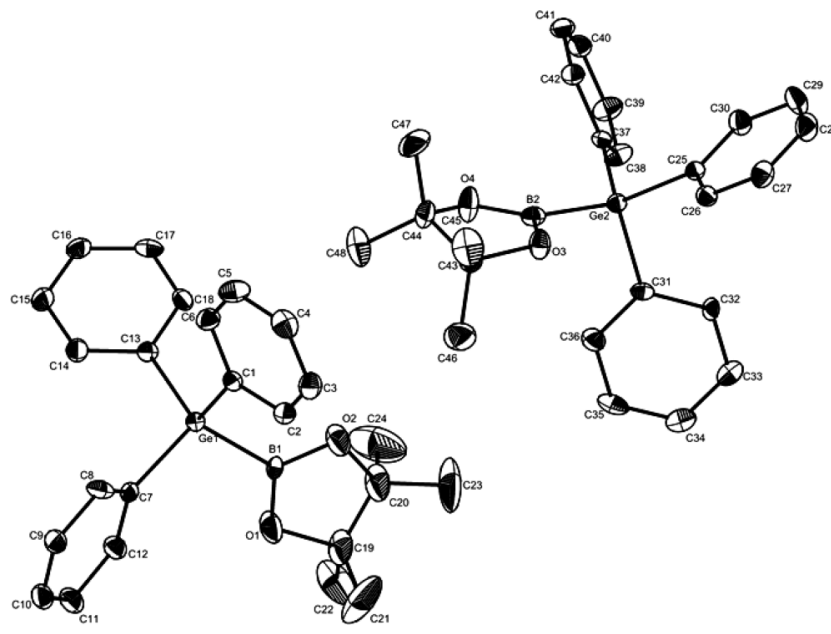

Fig. 2 The molecular structures of the two independent molecules of 1 with the atom labeling scheme. Displacement ellipsoids are drawn at the $30 \%$ probability level. Hydrogen atoms have been omitted for clarity.

F2(SHELXTL). ${ }^{8}$ The second twin component was much weaker and twin refinement did not lead to an improvement of the model. All non-hydrogen atoms were refined using anisotropic displacement parameters. Hydrogen atoms were included in calculated positions and refined using a riding model. A summary of the crystallographic data and structure refinements is presented in Table 1.

The molecular structure of complex $\mathbf{1}$ is shown in Fig. 2, and the selected bond lengths and angles are listed in Table 2. A crystal structure analysis confirms the formation of complex 1, which contains a three coordinate boron atom bonded to the bulky germyl group. The B-Ge bond distances for the two independent molecules in the asymmetric unit cell are 2.073(10) and 2.051(14) $\AA$, where the difference presumably arises from a solid-state packing effect. Nevertheless, these distances are similar to that found for 2-triphenylgermyl-(4-tert-butylcatecholato)borane, which was 2.054(2) $\AA$, suggesting a single B-Ge bond. ${ }^{9}$ The B-O bond distances and enlarged thermal parameters within the five-membered ring are typical for three coordinate boronate esters containing pinacol groups. ${ }^{10}$ Indeed, these short B-O distances (ranging from 1.320(11) to $1.386(13) \AA$ ) indicate that dative bonding between the oxygen lone pairs and the empty p-type orbital on the boron atom is significant in the title compound. Further studies on the reactivity of this germylboronate ester are currently underway, the results of which will be reported in due course.
Table 2 Selected bond lengths $(\AA)$ and angles $\left({ }^{\circ}\right)$

\begin{tabular}{lllc}
\hline \multicolumn{2}{c}{ Bond length } & \multicolumn{2}{c}{ Bond angle } \\
\hline $\mathrm{Ge}(1)-\mathrm{C}(13)$ & $1.943(5)$ & $\mathrm{C}(13)-\mathrm{Ge}(1)-\mathrm{C}(1)$ & $108.7(2)$ \\
$\mathrm{Ge}(1)-\mathrm{C}(1)$ & $1.958(5)$ & $\mathrm{C}(13)-\mathrm{Ge}(1) \mathrm{C}(7)$ & $108.4(2)$ \\
$\mathrm{Ge}(1)-\mathrm{C}(7)$ & $1.958(5)$ & $\mathrm{C}(1)-\mathrm{Ge}(1)-\mathrm{C}(7)$ & $107.9(2)$ \\
$\mathrm{Ge}(1)-\mathrm{B}(1)$ & $2.073(10)$ & $\mathrm{C}(13)-\mathrm{Ge}(1)-\mathrm{B}(1)$ & $114.1(4)$ \\
$\mathrm{Ge}(2)-\mathrm{C}(37)$ & $1.948(5)$ & $\mathrm{C}(1)-\mathrm{Ge}(1)-\mathrm{B}(1)$ & $108.3(2)$ \\
$\mathrm{Ge}(2)-\mathrm{C}(31)$ & $1.964(5)$ & $\mathrm{C}(7)-\mathrm{Ge}(1)-\mathrm{B}(1)$ & $109.3(4)$ \\
$\mathrm{Ge}(2)-\mathrm{C}(25)$ & $1.968(5)$ & $\mathrm{C}(37)-\mathrm{Ge}(2)-\mathrm{C}(31)$ & $107.5(2)$ \\
$\mathrm{Ge}(2)-\mathrm{B}(2)$ & $2.051(14)$ & $\mathrm{C}(37)-\mathrm{Ge}(2)-\mathrm{C}(25)$ & $108.48(19)$ \\
$\mathrm{B}(1)-\mathrm{O}(1)$ & $1.320(11)$ & $\mathrm{C}(31)-\mathrm{Ge}(2)-\mathrm{C}(25)$ & $107.3(2)$ \\
$\mathrm{B}(1)-\mathrm{O}(2)$ & $1.351(10)$ & $\mathrm{C}(37)-\mathrm{Ge}(2)-\mathrm{B}(2)$ & $113.8(4)$ \\
$\mathrm{B}(2)-\mathrm{O}(4)$ & $1.333(11)$ & $\mathrm{C}(31)-\mathrm{Ge}(2)-\mathrm{B}(2)$ & $109.2(4)$ \\
$\mathrm{B}(2)-\mathrm{O}(3)$ & $1.386(13)$ & $\mathrm{C}(25)-\mathrm{Ge}(2)-\mathrm{B}(2)$ & $110.4(2)$ \\
& & $\mathrm{O}(1)-\mathrm{B}(1)-\mathrm{O}(2)$ & $112.3(8)$ \\
& & $\mathrm{O}(4)-\mathrm{B}(2)-\mathrm{O}(3)$ & $112.7(10)$ \\
\hline
\end{tabular}

\section{Acknowledgements}

Thanks are gratefully extended to the Natural Sciences and Engineering Research Council of Canada, the Canada Research Chairs Program, and Mount Allison University for financial support and to an anonymous reviewer for their helpful comments.

\section{References}

1. M. Oestreich, E. Hartmann, and M. Mewald, Chem. Rev., 2013, 113, 402.

2. M. Suginome and Y. Ito, J. Organomet. Chem., 2003, 680, 43.

3. M. G. Civit, X. Sanz, C. M. Vogels, J. D. Webb, S. J. Geier, A. Decken, C. Bo, S. A. Westcott, and E. Fernández, J. Org. Chem., 2015, 80, 2148.

4. E. N. Daley, C. M. Vogels, S. J. Geier, A. Decken, S. Doherty, and S. A. Westcott, Angew. Chem. Int. Ed., 2015, $54,2121$.

5. CELL_NOW, V. 2008/2, George Sheldrick, Bruker AXS, Inc., Madison, Wisconsin, USA.

6. SAINT 7.23A, 2006, Bruker AXS, Inc., Madison, Wisconsin, USA.

7. SADABS 2008, George Sheldrick, 2008, Bruker AXS, Inc., Madison, Wisconsin, USA.

8. G. M. Sheldrick, Acta Cryst., 2008, A64, 112.

9. T. Habereder and H. Nöth, Appl. Organomet. Chem., 2003, 17, 525 .

10. S. Hawkeswood and D. W. Stephan, Dalton Trans., 2005, 2182. 